\title{
Harnessing the Language Diversity through the National Youth Service Corps (NYSC) Programme in Multilingual Nigeria: Synergising our Separation
}

\author{
Dr. Akinwamide T.K.* \\ Arts and Language Education Department, Ekiti State University, Ado Ekiti, Nigeria
}

*Corresponding Author: Dr. Akinwamide T.K., Arts and Language Education Department, Ekiti State University, Ado Ekiti, Nigeria

\begin{abstract}
Nigeria is one of nation states on the continent of Africa whose cultures, languages and other national identities were not defined before their formations. The 'mandatory marriage' between the predominantly Christian Southern protectorate and the predominantly Muslim Northern protectorate in 1914- without prior consultation with other ethnic nationalities created a national identity question that continues to pervade the modern Nigeria state (Momah, 2013). Consequent upon this, youth education in integration of multicultural traditions and ethno-regional mandates; narrowing the gaps between rural-urban livelihoods; bridging the divides between ethnic and geographical access to resources, and developing a national identity was envisaged as an integral aspect in addressing nation-building problems (Abuduntu, 2010; Ibukun and Aboluwodi, 2010).
\end{abstract}

Keywords: Separation, Synergy, Youth-Corps, Integration, Unity, Indegenuos Language

\section{EDUCATION AND THE QUEST FOR NATIONAL DEVELOPMENT}

Education in Nigeria is an instrument "par excellence" for effecting national development. It has witnessed active participation by non-governmental agencies, communities, and individuals as well as government intervention (E Obadare, 2005). _It is therefore desirable for the Nation to spell out in clear and unequivocal terms the philosophy and objectives that underlie its investment in education. The National Policy on Education seeks to fulfil that role.

The need for a national policy on education came about as a result of the 1969 National Curriculum Conference which was attended by a cross-section of Nigerians. The conference was a culmination of expressions of general dissatisfaction with the existing education system which had become irrelevant to national needs, aspirations and goals (Obadare,2005).

After the National Curriculum Conference, a seminar of experts drawn from a wide range of interest groups within Nigeria was convened in 1973. The seminar, which included voluntary agencies and external bodies, deliberated on what a national policy on education for an independent and sovereign Nigeria should be.

The outcome of the seminar was a draft document which; after due comments were received from the states and other interest groups, led to the final document, the National Policy on Education, first published in 1977. According to the National Policy on Education, the objectives are as follows:

- the inculcation of national consciousness and national unity;

- the inculcation of the right type of values and attitudes for the survival of the individual and the Nigerian society;

- the training of the mind in the understanding of the world around; and

- the acquisition of appropriate skills and the development of mental, physical and social abilities and competencies as equipment for the individual to live in and contribute to the development of the society.

Nigerian educational system was modelled after British model. The model is bereft of lofty realities that place indigenization into the curriculum compendium and self- reliance. These models were 
Harnessing the Language Diversity through the National Youth Service Corps (NYSC) Programme in Multilingual Nigeria: Synergising our Separation

based on the same problematic 'moral prisms' that guided mainstream development theory. The institutionalization of colonial models of development in Nigeria conceptualised youths as key agents in constructing a Nigerian identity (Halloway, 2013).

\section{National Language Policy and Medium of Instructions in Schools}

That Nigeria is extremely linguistically diverse is evident from the number cited in each classification done on the number of languages in Nigeria (Dada 2013). Bamgbose (1971) there are about 450 indigenous languages in Nigeria. However, the 2005 Ethnologic Data listed 521 languages for Nigeria. Of these, 510 are living languages 2 are second languages without mother tongue speakers, and 9 are extinct.

The five hundred and ten indigenous living Nigerian languages, as expected, cannot all function as the official language of Nigeria. Nigeria, just like any other African nation, is not like some modern European nations that are linguistically homogenous. These Nigerian languages have been variously categorized and re-categorized as major or minor or class I, class II or class III, etc., using a number of factors such as the population of speakers, range of functions/domains of use, level of linguistic analysis, etc. (Adekunle, 1976; Bamgbose, 1985; Agheyisi, 1981; Odumuh, 1993; Oyetade 2002 among others). For instance, Brann (1992) classifies Nigerian languages into three levels as follows: major languages, state languages and local languages, based on their status as dominant languages, their territorial spread and the population that speaks them. With this categorization, there are three major languages in Nigeria, thirteen state languages and over forty-four local languages while those languages considered as either too small or non-dominant speech forms in any existing political or administrative territory were unlisted (Dada 2013)

Indeed, going by the Ethnologic data report for Nigeria, some of these five hundred and ten living Nigerian languages have as low as 400-100 speakers. Examples include: Janji, Benue-Congo language spoken in Bassa LG, Plateau State, Jilbe, Afro-Asiatic language spoken in Borno State, Ndunda, Niger-Congo language spoken in Taraba State etc. Thus, such languages can be rightly categorized without sounding derogatory anyway as minor languages used mainly at home, village and local community levels. About 75 percent of the total figures of the Nigerian indigenous languages belong to this core (Dada 2013).

Hausa, Yoruba and Igbo are the three major languages in Nigeria. The 1979 and 1999 Constitutions recognize them as national languages. They are used as regional languages in Nigeria with the Hausa language in the North, the Yoruba language in the West and the lgbo language is in the South-eastern Nigeria. They are, however, not restricted to intra-group communication. 'Although the exact population of mother tongue speakers of the major languages is not known, the population of each of the three languages, is probably over 20 million people' (Igboanusi \& Peter 2005:5). Hence, they are the mother tongues of about half of Nigeria's population, acquired at home but also taught in schools as subjects.

Linguistic pluralities resulting from the language situation made Nigeria adopt English language as her official language. The English language is a language of convenience, which has helped to weld together the various ethno-linguistic groups in the country (National Policy on Education, 2004). It thus became the language of instruction in multilingual Nigerian schools.

\section{YOUTH EMPOWERMENT AND NATIONAL UNITY}

Nigeria Youth Service Corps (NYSC) - a product of federal military government of the Gowon's Regime, which was established as a post-civil war intervention in 1973 became institutionalized under decree No.24, with the purpose of:

- promoting national unity

- fostering common socio-cultural ties among the youths of Nigeria

- and integration of the teaming youth population (NYSC, 1999)

In Nigerian context, it can be observed from the national youth policy declaration, that there are variations between the general definition of a youth - i.e. a person between ages 18 and 35 years and the organisational youth corps classifications of a youth - i.e. a person between ages 18 and 30 (NYSC, 1999; NYSC ACT, 2004; FMYD, 2009).The target youth group for this programme are young Nigerian graduates, eligible to participate in the National Youth Service Corps (NYSC) (i.e. 
Harnessing the Language Diversity through the National Youth Service Corps (NYSC) Programme in Multilingual Nigeria: Synergising our Separation

persons between ages 18-30). Nigerian graduates are mobilized and brought together from the various ethnic backgrounds, regardless of religious beliefs, country/state of study and cultural affliation, for the purpose of 'national building' and development.

The objectives of the scheme as contained in section 1 (3) of the enabling legislation are:

- to inculcate discipline in Nigerian youths by integrating in them a tradition of industry at work and of patriotic and loyal service to the Nation in any situation they may find themselves;

- to raise the moral tone of our youths by giving them the opportunity to learn about higher ideals of national achievement and social and cultural improvement;

- to develop in our youths attitudes of mind, acquired through shared experience and suitable training, which will make them more amenable to mobilization in the national interest;

- to develop common ties among our youths and promote national unity by ensuring that:

$>$ as far as possible youths are assigned to jobs in states other than their states of origin;

$>$ each group, assigned to work together, is as representative of the country as possible;

$>$ the youths are exposed to the modes of living of the people in different parts of the country, with a view to removing prejudices, eliminating ignorance and confirming at first hand the many

As a matter of fact, immediately it was established, the NYSC became an operational vehicle for harnessing and showcasing the collective capabilities of Nigerian youths for Nigeria's national development drive through its youth deployment strategy into key sectors of the economy (Obadare, 2010; Raimi and Alao, 2011). The scheme consists of four phases: Mobilization; Orientation; Primary Assignment and Community Development Service; and Winding up Activities - Passing-Out-Parade. The key fields to which corps members were to be deployed as mentioned in the enabling decree included hospitals, farms, water-schemes, road construction, surveying and mapping, social and economic services, schools, food storage and pest eradication, rehabilitation centres, sports development, government departments and statutory corporations, development projects of local councils and the private sector of the economy (Iyizoba 1982, 4).

Initially, the service was divided into primary and secondary assignments. For the primary assignment, each of the corps members was deployed to perform his national service in a field relevant to his qualification. The secondary assignment takes four weeks and involves mobilization in groups to perform community and rural development in various locations (Ibid). A major concern however is the recent Federal Government approved NYSC deployment strategy into only four key sectors of the economy (agriculture, education health and rural infrastructure development) would potentially leave a significant proportion of youths as a development 'mis-match' with far-reaching implications including a missed opportunity for diversified youth capacity development (FMYD, 2013a; NYSC, 2014).

\section{EXPLORING THE LANGUAGE OPTION; FROM SEPERATION TO SYNERGY}

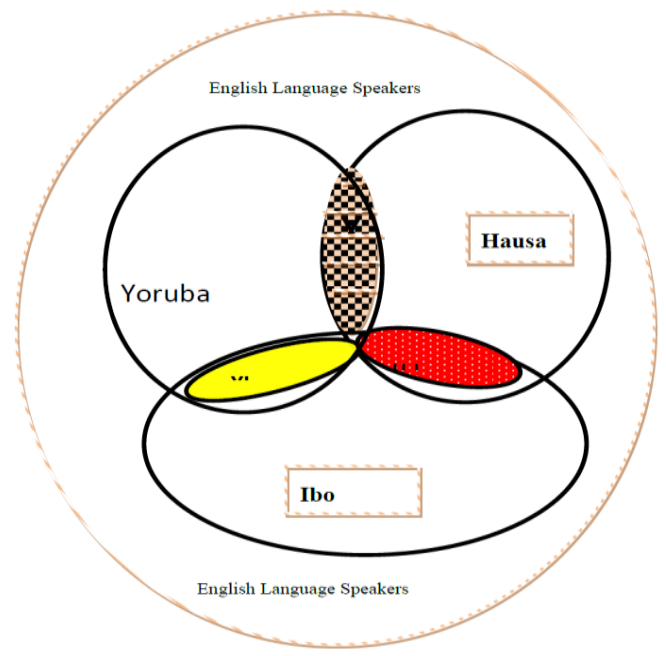


KEY: Yoruba, Ibo, Hausa, YH : Amalgam of Yoruba and Hausa (Yoruba and Hausa Copers), YI : Amalgam of Yoruba and Ibo (Igbo and Yoruba Copers), IH : Amalgam of Ibo and Hausa (Hausa and Igbo Copers)

From the above, the language option can be seen in YH, YI \& IH which emerged as a result of language integration as a result of youth deployment to new language environment. The corp members are sent to new language settings which usually gives birth to amalgam of languages thus widening the scope and increasing the percentage of those speaking any of the local languages. The resultant effect of this is increment in the number of multilinguals in the country and cross-cultural alliance is established.

Emenanjo(2004) observes that Nigerian Languages have a lot to contribute to the evolution and success of democratic culture, national development and integration. He suggests egalitarian multilingualism and full empowerment of Nigerian languages as vehicles of communication. By egalitarian multilingualism he means assignment of equal weight to three major indigenous languages in Nigeria- Hausa, Igbo and Yoruba. According to him, through literacy; Nigerian languages can become veritable instruments for the full empowerment of the Nigerian youths, and thus makes them appreciate fully its workings, its values and indeed its existence as a way of life.

Acculturation is a youth empowerment strategy aiming at providing instruction for the study of Nigerian languages as second language (L2).This programme is offered by Colleges of Education and Universities, and it involves only the three major Nigerian languages. There are three language centres in Nigeria responsible for the language immersion programmes: Kano for Hausa, NINLAN Aba for Igbo, and Oyo for Yoruba (Olaoye, 2013). Students and individuals who speak these languages as mother tongue do not need acculturation. Acculturation is a practical - oriented programme which started with the implementation of the NPE (Uluocha, 2000). It was designed to promote national integration.

The objective of acculturation is to facilitate inter-ethnic understanding and national unity. The acculturees make friends, exchange views, learn the host culture and borrow some aspects of the host cultures. Through interactions they later relate with their colleagues academically, socially, economically, politically and religiously. This promotes bilingualism with all its advantages (Olaoye, 2013).

National Institute for Cultural Orientation(NICO), a parastatal of the Federal Ministry of Culture and Tourism, has taken up the challenge in indigenous languages acculturation programme. Language immersion programmes have in recent past been organised on zonal basis to cater for the communicative language needs of youths as well as interested members of the public. It is a language courses in Nigerian indigenous languages for a period of four weeks.

At Ilorin in 2012, language immersion programme in Yoruba, Hausa, Nupe, Tiv, Igbo, Izon and Batonu was organised for interested members of the public with National Youth Corps members as their primary targets. In a similar vein, another programme was organised in Adamawa the same year with the National Youth Service Commandant in the state commenting that due to language barrier, communicating with the indigenous people had been a herculean task, for nine year as the NYSC commandant in Adamawa state, but having demonstrated maximum confidence after completing four week language course, the barrier is over.

Graduates of Nigerian universities are ethnically swapped for their youth service scheme. The major language of communication they rely on is English language which is bedevilled by low literacy level of people in places of their primary assignment. The vogue within the scheme is that the corps are to learn the language of their immediate environment without policy backup. Yet the corps members have to interact with their host communities in schools, churches, markets and other social gatherings. Invariably, the Corp Members learn the new indegenous language which is quite advantageous to the unity of the country.

\section{CONCLUSiON}

Language - a human phenomenon, which is the basic means of communication among the world citizens has generated 'a great divide' as a result of non understanding of terms, patters and words in different languages of the world. Our cultural heritages are expressed basically in our languages. Kaplan 2012 says language is how individuals communicate, acquire knowledge, and work with 
Harnessing the Language Diversity through the National Youth Service Corps (NYSC) Programme in Multilingual Nigeria: Synergising our Separation

others. It is how societies pass on culture and institutions, import new ideas and technology, and forge links among members. It can unite as well as divide, act as an instrument of empowerment as well as a barrier to advancement, and influence how societies evolve. This aptly explains the divide in multilingual nations like Nigeria. It is in this perspective that political upheaval is seen for example in Nigeria insomuch that a thorough assessment of the political landscape of the country can be traced to language sentiments. Every region tilts politically towards a domiciled political party in that region. Hubbard 2008 says at the root of every confusion and restlessness is the misunderstood language. It is the greatest barrier to study, peaceful coexistence and bilateral relations. In multilingual countries like Nigeria where there is one foreign language as an official language, such policy inherently cuts off the majority non-elite. Suspicion, schism and separation usually dominate the polity but with programme like the NYSC in place, a lot of dividends can be harness from our language divides.

\section{REFERENCES}

[1] Abutudu, M. (2010): Federalism, Political Restructuring, and the Lingering National Question. In, Adejumobi, S. (2010):Governance and Politics in Post- Military Nigeria: Changes and Challenges. New York: Palgrave Macmillan.

[2] Adekunle, M.A. (1976) "National Language Policy and Planning: the Nigerian Situation" West African Journal of Modern Languages, 1: 23-29.

[3] Agbeyisi, RN. (1989) "Minor Languages and the National Question: Problems and Prospects" Savanna, 10 (2): 10-17.

[4] Bamgbose, Ayo (1971) “The English Language in Nigeria: In Spencer, J. (ed.)

[5] The English Language in West Africa London: Longman Bamgbose, Ayo (1985) "Language and Nation Building”.Review of English and Literary Studies Vol. 2, No. 2 pp. 95-108.

[6] Bah, A.B. (2005): Breakdown and Reconstitution: Democracy, the Nation-state, and Ethnicity in Nigeria. Lanham, MD: Lexington Books.

[7] Bodley-Bond, C. and Cronin, K. (2013): National youth service, employability, entrepreneurship and sustainable livelihoods: Overview of the national youth service landscape in Sub-Saharan Africa. Washington DC: Innovation in Civic Participation.

[8] Brann, C.B.M (1992) "Beyond Rhetoric: From Theory to Practice in Teaching Nigerian Language as Second Language in Tertiary Institutions". The Ekiadolor Journal of Education 3.

[9] Dada, S.A (2007) "Language Contact and Language Conflict: The Case of Yoruba- English Bilinguals". In Kansas Working Papers in Linguistics (forthcoming).

[10] Emenanjo, Nolue. (2004). Nigerian languages and the democratic experience. In: Nigerian languages and the Democratic Experience. Proceedings of the 9th annual conference of ANLAT, NINLAN Aba, Nigeria.

[11] Falola, T. and Heaton, M.M. (2008): A history of Nigeria. Cambridge: Cambridge University Press.

[12] NYSC (2014): NYSC Magazine, The Journal of NYSC Directorate Headquarters. Abuja: National Youth Service Corps Service.

[13] Ibukun, W.O. and Aboluwodi, A. (2010): Nigeria's National Policy on Education and University Curriculum History, Journal of Educationand Practice, vol 1(2), p. 9-17.

[14] Igboanusi, Herbert and Lothar Peter (2005) Languages in Competition. The Struggle for Supremacy among Nigeria's Major Languages. English and Pidgin. Frankfurt an Main: Peter Lang.

[15] Igboanusi, Herbert and Lothar Peter (2005) Languages in Competition. The Struggle for Supremacy among Nigeria's Major Languages. English and Pidgin. Frankfurt an Main: Peter Lang.

[16] National Policy on Education Federal Republic of Nigeria (1981), (Revised) Lagos: Federal Government Press.

[17] Obadare, Ebenezer (2005). Statism, Youth and Civic Imagination: A Critical Study of The National Youth Service Corps (NYSC), Centre for Civil Society, Old Building, Houghton Street, London.

[18] FMYD (2013a): 2013 Ministerial Platform Presentation: Mid-Term Report of the Ministry of Youth Development, Abuja: Federal Ministry of Youth Development, Nigeria.

[19] Obadare, E. (2010): Statism, Youth and Civic Imagination: A critical Study of the National Youth Service Programme in Nigeria, CODESRIA Monograph Series, Council for the Development of Social Science Research in Africa. Dakar: CODESRIA.

[20] Odumuh, A.E. (1993) "Nigerian Languages in Government and Administration". Ayo

[21] Olaiya, T.A. (2014): Youth and Ethnic Movements and their Impacts on Party Politics in ECOWAS Member States, Sage Open, p. 1-12. 
Harnessing the Language Diversity through the National Youth Service Corps (NYSC) Programme in Multilingual Nigeria: Synergising our Separation

[22] Olaoye, A.A. (2008). Language education as a weapon for youth empowerment: $a$ linguistic strategy for achieving aspects of MDGs.Paper presented at the University of Abuja International conference.

[23] Onuoha, F.C. (2014): Why do youth join Boko Haram? Washington DC: United States Institute of Peace.

[24] Oyetade, S. Oluwole (2002) "Language Policies and Planning in Nigeria" Research in African Languages and Linguistics Vol. 6, pp 51-66.

[25] Raimi, L. and Alao, O. (2011): Evaluation of the economics (cost and benefits) of National Youth Service Corps for sustainable development in Nigeria, Humanomics, Vol. 27(4), 270-281.

[26] Uluocha, V.C. (2000). The role of Nigerian language acculturation. In: Language, Literature and Linguistics in the 21stCentury. Kaduna: NCCE.

Citation: Dr. Akinwamide T.K. "Harnessing the Language Diversity through the National Youth Service Corps (NYSC) Programme in Multilingual Nigeria: Synergising our Separation" International Journal of Humanities Social Sciences and Education (IJHSSE), vol 6, no. 1, 2019, pp. 75-80. doi: http://dx.doi.org/10.20431/2349-0381.0601009.

Copyright: (C) 2019 Authors. This is an open-access article distributed under the terms of the Creative Commons Attribution License, which permits unrestricted use, distribution, and reproduction in any medium, provided the original author and source are credited. 